\title{
The Effect of Task-Based Language Teaching on Students' Speaking Achievement at the First Grade of SMAN 1 Bandar Lampung
}

\author{
Oleh: \\ Kory Dita Iswari*; Mahpul; Gede Eka Putrawan \\ FKIP University of Lampung, Jl. Prof. Dr. Soemantri Brojonegoro No.1 \\ *email: korydita133@gmail.com, Telp:08975523597
}

\begin{abstract}
Abstrak. Tujuan penelitian ini adalah untuk mengetahui kendala-kendala dalam pengajaran berbicara menggunakan TBLT pada siswa tingkat pertama di SMAN 1 Bandar Lampung. Penelitian ini adalah penelitian kualitatif. Sasaran penelitian ini adalah 29 siswa tingkat pertama SMAN 1 Bandar Lampung. Observasi dan wawancara digunakan sebagai alat untuk pengambilan data. digunakan untuk mengumpulkan data dari performa siswa. Hasil penelitian menunjukkan bahwa kendala-kendala dalam pengajaran berbicara menggunakan TBLT adalah peran guru dalam memberikan perintah, peran tugas itu sendiri dan pengetahuan dasar siswa khususnya pada bentuk bahasa dan kosakata. Dapat disarankan bahwa pengajaran berbicara menggunakan TBLT dapat membantu siswa untuk mengungkapkan gagasan-gagasan dan membuat siswa lebih aktif di dalam kelas.
\end{abstract}

\begin{abstract}
The aim of this study was to find out the constraints of teaching speaking using TBLT on students' speaking achievement at the first grade students of SMAN 1 Bandar Lampung. This was a qualitative research. The subjects were 29 students of the first grade of SMAN 1 Bandar Lampung. Observation and interview were used as the research instruments. The result of the research showed that the contraints of teaching speaking using TBLT were the role of teacher in giving instructions, the role of task itself, and students' background knowledge especially on language forms and vocabularies. This suggests that speaking through TBLT helps students express their ideas and makes them more active in the class.
\end{abstract}

Keywords: Task-Based Language Teaching, speaking, achievement. 


\section{INTRODUCTION}

Since almost all of the people use oral communication to communicate, speaking is preferred rather than writing for simply maintaining communication. Speaking is used to bridge one to other individuals in their environment. Speaking is a process of producing and receiving meaningful sound using organ of speech and non verbal symbols like gesture and facial expression. Brown (in Burns and Joyce, 1997) states that speaking is an interactive process of constructing meaning involving producing, receiving and processing information. Speaking is a very important thing when it comes to the learning process, especially in learning English.

Various kinds of speaking activities cannot be split from learning process of mastering English. However, most schools in Indonesia still use a traditional method to teach English to the students. They emphasize on the use of grammar than speaking activity in class. Lack of tasks in speaking skills is the problem why many students find it hard to speak English. This statement is supported by Richards (1990:233) who states that the English learners failed in speaking activity are caused by lack of curriculum focusing on speaking skills, the limited of teachers in English proficiency, the monotonous class athmosphere, minimum practice done outside the class, and the examination system which does not emphasize on speaking skills. To make students speak more in the class, teachers need to use a method which encourages students to speak in class.

Methods which enable students to communicate actively in effective and meaningful activities in the classrom are believed as the answers to solve this problem. Those classifications are found in Task-Based Language Teaching method. According to Sofyana (2015), Ellis (2003) states that Task-Based Language Teaching (TBLT) is a form of teaching that treats language primarily as a tool for communicating rather than as a subject for study or manipulation. TBLT is based on the real world or target task by using language. Since this method is students-centered, it demands the students' involvement and creativity in the speaking activity. In line with the explanation above, TBLT emphasizes on the real-world activities. It means that TBLT focuses on interaction and communication among the students who do the task using the appropriate language at the correct time.

In TBLT, students are encouraged to do tasks spontaneously and creatively. The tasks are usually in form of performance tasks and problem solving since the purpose of TBLT is making students more active by themselves. Problem solving is a process of applying a method - not known in advance to a problem that is subject to a specific set of condition and that the problem solver has not seen before in order to obtain a satisfactory solution. Ormond (2006:111) notes that problem solving is using existing knowledge and skills to address an unanswered question or troubling situation. Problem solving demands students to think creatively. Students should express their own opinion to give solution based on the problem appeared. 
Based on the previous research conducted by Fandana (2013) problem solving can increase students' speaking ability better and overcome the problem given to them during the treatment of teaching learning process. The highest progress was the students' fluency and comprehension in speaking. On the other hand, the lowest progress was pronunciation. This findings is in line with Hedge's (2000) who claims that the teacher will say that pronunciation is one of the most difficult area for students. Another research conducted by Sofyana (2015) shows that the implementation of Task-Based Language Teaching through Cartoon Story Maker effectively improved the students' speaking ability. The data collected from the observation showed that the students enthusiasticly participated in learning activity through cartoon story maker in TBLT and TBLT also encouraged them to speak English without hesitation.

Based on the previous research with respect to TBLT, the current study focused on investigating the constraints of teaching speaking using TBLT.

\section{METHODS}

This study was qualitative research which was elaborated in descriptive elaboration. The researcher used one class as the subject of the research. The research was conducted at the first grade of SMAN 1 Bandar Lampung in which the sample was Class X MIPA 2 consisting of 29 students in the second semester of academic year 2016/2017. The observation was applied during the treatments to investigate the students' activities and constraints in learning speaking process, and interview was conducted after the treatments to know the students' response after being taught through Task-Based Language Teaching.

The treatments were in two meetings with two kinds of task topics. To make it suitable for the subjects, both the materials and the topics of the test were adapted from the curriculum 2013.

\section{RESULTS}

Table 1. The Observation Sheet Result on Task 1 and Task 2

\begin{tabular}{|c|c|c|c|c|c|c|}
\hline \multirow[b]{2}{*}{ No } & \multirow[b]{2}{*}{$\begin{array}{l}\text { Students' } \\
\text { Activities }\end{array}$} & \multirow[b]{2}{*}{ Constraints } & \multicolumn{2}{|c|}{ Task 1} & \multicolumn{2}{|c|}{ Task 2} \\
\hline & & & Freq. & $\begin{array}{c}\text { Percen } \\
\text { tage }\end{array}$ & Freq. & $\begin{array}{c}\text { Percen } \\
\text { tage }\end{array}$ \\
\hline \multirow[t]{2}{*}{1.} & \multirow[t]{2}{*}{ Pre-task } & $\begin{array}{l}\text { Being confused with the } \\
\text { instruction of the task. }\end{array}$ & 20 & $69 \%$ & 5 & $17 \%$ \\
\hline & & $\begin{array}{l}\text { - Being uninterested with the use } \\
\text { of picture. }\end{array}$ & 7 & $24 \%$ & 3 & $10 \%$ \\
\hline \multirow[t]{2}{*}{2.} & \multirow[t]{2}{*}{$\begin{array}{l}\text { During } \\
\text { task }\end{array}$} & $\begin{array}{l}\text { - Translating and using their L1 a } \\
\text { lot than the target language in } \\
\text { completing the task. }\end{array}$ & 17 & $58 \%$ & 10 & $34 \%$ \\
\hline & & $\begin{array}{l}\text { Feeling burdened to complete } \\
\text { the similar kind of task. }\end{array}$ & 14 & $48 \%$ & 12 & $41 \%$ \\
\hline 3. & Post-task & $\begin{array}{l}\text { Unable to notice language form } \\
\text { and other elements of accuracy } \\
\text { in reflection session. }\end{array}$ & 20 & $69 \%$ & 7 & $24 \%$ \\
\hline
\end{tabular}


Table 1. shows the constraints of teaching speaking when the researcher implemented Task-Based Language Teaching in both the treatments. Based on the observation data, overall, most of the students actively participated in learning activity using Task-Based Language Teaching. Then, there were three points observed in learning process; pre-task, during task, and post-task. Referring to the two task, it can be seen that there were five constraints found in teaching speaking using Task-Based Language Teaching. First, in Task 1, there were two constraints found on the pre-task stage. There were 20 students (69\%) who were confused with the instruction of the task and there were 7 students (24\%) who were uninterested with the use of picture. Compared to Task 1, in the same number of constraints, Task 2 shows that there were an decrease on the number of students experiencing difficulties in learning speaking through Task-Based Language Teaching. In Task 2, there were also two constrains found on the pre-task stage. There were 5 students (17\%) who were confused with the instruction of the task and there were 3 students $(10 \%)$ who were uninterested with the use of picture. The constraints appeared when the researcher brainstormed and gave the students a warming-up task using picture in the pre-task.

Second, in Task 1, there were two constraints found on the during task stage. There were 17 students (58\%) who were translating and using their L1 a lot than the target language in completing the task and there were 14 students (48\%) who were feeling burdened to complete the similar kind of task. Compared to Task 1, in the same number of constraints, Task 2 shows that there were an decrease on the number of students experiencing difficulties in learning speaking through Task-Based Language Teaching. In Task 2, there were also two constraints found on the during stage. There were 10 students (34\%) who were translating and using a lot of their L1 than the target language in completing the task and there were 12 students $(41 \%)$ who were feeling burdened to complete the similar kind of task. The constraints appeared when the students discussed the problem and prepared the performance with their partner related to the task given.

Third, both in Task 1 and Task 2, there was one constraint found on the post-task stage. In Task 1, there were 20 students $(69 \%)$ who were unable to notice language form and other elements of accuracy in reflection session while in Task 2 there were 7 students (24\%) who were unable to notice language form and other elements of accuracy in reflection session. It shows that there were an decrease on the number of students experiencing difficulties in learning speaking through Task-Based Language Teaching. The constraint appeared when the researcher gave feedback and reflected the students' performance.

Besides observation, the researcher also did an interview to the students in order to support the data from observation. Some of the interview chunks were taken to be analyzed in order to see the constraints of teaching speaking using Task-Based Language Teaching.

Bagian memecahkan masalahnya, Miss. Karena ceritanya seperti nyata gitu. Jadi seperti kita benar-benar harus memecahkan masalahnya. (In problem solving part, Miss. Because the story in the task seemed so real. It was like we should solve the problem.) 
The first interview chunk indicates that the students rarely had kind of task demanding the students to solve the problem and give opinions and thoughts related to the problem in the task.

Membantu. Soalnya biasanya kami hanya mengerjakan LKS (students' worksheet), jarang sekali dapat pembelajaran speaking, Miss.

(Yes, it did. We usually just did students' worksheet in the class and we rarely had speaking session, Miss.)

The second interview chunk indicates that the students rarely had speaking activity in their learning activity. They usually just had grammar session in the class.

Karena biasanya kita hanya mengerjakan satu macam tugas, kali ini ada rangkaian tugas, lebih menguras energi.

(Because usually we just did one kind of task and with you, we had a series of tasks, we made more effort to do the tasks.)

The third interview chunk indicates that the task given by the researcher demanded more students' effort since their habit in learning activity was doing grammatical exercises.

\section{DISCUSSION}

The result of the observation sheets show that there were five constraints in teaching speaking appeared in the learning activity using Task-Based Language Teaching through problem solving. It is proven by the result data in the first and second meeting of the treatments. The constraints were being confused with the instruction of the task, being uninterested with the use of picture, translating and using their L1 a lot than the target language in completing the task, feeling burdened to complete the similar kind of task, and unable to notice language form and other elements of accuracy in reflection session.

Based on the observation data, overall, most of the students actively participated in learning activity using Task-Based Language Teaching. This finding is in line with Sofyana (2015) research showing that the data collected by the observation showed that the students enthusiasticly participated in learning activity through cartoon srory maker in TBLT and TBLT also encouraged them to speak English without hesitation.

The first constraint appeared in observation was the students were confused with the instruction gave by the teacher in the pre-task. Some students could not catch the instruction meaning and they tended to keep silent even when the teacher asked them some questions related to the task. Then, another constraint appeared in pre-task stage was some of them also were not interested in the use of picture in the pre-task. The target of use of picture with some guiding questions was to direct the students to prepare their task in during task stage. According to Willis (1996), the purpose of the pre-task stage is to activate students' own linguistic resources to prepare them for the task cycle. Then, when the teacher used a media 
of picture to pull the students to be involved in the talk, they did not show any intention to respond the teacher's question related to the picture.

The constraints appeared in during task stage were the some students translated and used a lot of their L1 than the target language in completing the task and the students felt burdened to complete the similar kind of task. These students frequently used Bahasa Indonesia rather than English during doing the task. The more they used Bahasa Indonesia and used Indonesian context, the more the task flowed smoothly. According to Swain and Lapkin (2000), pupils used the first language for three main purposes: moving the task along, focusing attention, and interpersonal interaction. Then, some of the students felt burdened to complete the similar kind of task since they were not used to do a series of tasks in pre-task stage and in during task stage.

The last constraint found by the researcher was some of the students were unable to notice language form and other elements of accuracy in reflection session. Most of the students realized the mistakes they made and they made the correction after the researcher gave some clues to the mistakes. On the other hand, some of them could not find their mistakes in their performance. For this case, the researcher showed the mistake directly to the students. This is in line with Jones (2007) statement stated that the best time to give students feedback on their performance by mentioning some mistakes that the teachers overheard would be by the time the task is done.

Besides, based on the observation done by the researcher, the students involved more in the speaking activity using TBLT because they rarely had such kind of this task in their learning activity. It is strengthened by the interview result stated that the students assumed that the task was interesting since it was a kind of realworld task. Since the tasks looked interesting to them, they were motivated to perform the task. In line with Lochana and Deb's (2006) findings, TBL is beneficial to learners not only in terms of proficiency enhancement but also in terms of motivation. The chunk indicating the students' fondness towards the task is enlightened below.

Researcher

: Bagian manakah yang membuat kalian senang dalam belajar menggunakan metode tadi?

(Which part of the learning made you interested in learning English using that method?)

Dwischa : Bagian memecahkan masalahnya, Miss. Karena ceritanya seperti nyata gitu. Jadi seperti kita benarbenar harus memecahkan masalahnya.

(In problem solving part, Miss. Because the story in the task seemed so real. It was like we should solve the problem.)

The proof is strengthened by Bygate (2000) who states that the interest in tasks comes from the belief that they are 'a significant site for learning and teaching'.

By looking at the result of the interview, it shows that the students, in the beginning, felt hard and challenged to implement Task-Based Language Teaching 
method into their learning activity when they were asked to analyze and give their opinion toward the problem read by them after comprehending the case in the task. This was supported by the notion established by Willis (1996) who suggests that TBLT is seen as a method fostering a learning environment that finds appropriacy in all skills and often combines more than one skill in the same task. The result of the interview points out that one of the contraints of teaching speaking using TBLT are the background knowledge and learning habitual of the students. It also shows that the students are not used to speak English in the learning activity because the teacher usually emphasizes on the grammar exercises which focuses on the theory rather than practising speaking. It is showed on the chunk of interview below.

Researcher : Pembelajaran seperti tadi, contohnya tadi saya kan memakai Problem Solving, membantu tidak dalam pembelajaran speaking?

(In the learning we just did, I used Problem solving, did it help you in learning speaking?)

Renaldy : Membantu. Soalnya biasanya kami hanya mengerjakan LKS (students' worksheet), jarang sekali dapat pembelajaran speaking, Miss.

(Yes, it did. We usually just did students' worksheet in the class and we rarely had speaking session, Miss.)

It is in line with Richards (1990) who states that the English learners failed in speaking activity are caused by lack of curriculum focusing on speaking skills, the limited of teachers in English proficiency, the monotonous class athmosphere, minimum practice done outside the class, and the examination system which does not emphasize on speaking skills.

As stated in the interview, the students expressed their difficulties in doing the tasks. In the beginning of the treatment, the students also had to make more effort to do the task. It is because in TBLT the students have to do the series of task, even it is doing similar task. This finding is supported by Ellis (2003) who states Task-Based Language Teaching is method to teaching a second/ foreign language that seeks to engage the learners in interactionally authentic language use by having them perform a series of task. It seems from the chunk of the interview below.

Tiara : Karena biasanya kita hanya mengerjakan satu macam
tugas, kali ini ada rangkaian tugas, lebih menguras
energi.
(Because usually we just did one kind of task and with
you, we had a series of tasks, we made more effort to do
the tasks.)

Besides, from the result of interview, the constraint in teaching speaking using TBLT was the selection of the words to be uttered, because based on their reason they only mastered limited words, especially lexical words. Lack of vocabulary 
mastery become the problem when they had to perform their performances. Based on the data of the speaking aspects' improvement, complexity is the least aspect increased.

In brief, based on the observation and interview result, the researcher concluded that the contraints of teaching speaking using Task-Based Language Teaching (TBLT) could be seen from the teacher's point of view and students' point of view. From the teacher's side, the constraints were the role of teacher in giving instruction and the role of task itself. From the students' side, students' background knowledge, especially on language forms and vocabulary, was the constraint found in the teaching speaking using TBLT. It appeared when the students did the task in during task and in the reflection of performance session in post-task.

\section{CONCLUSIONS}

The contraints of teaching speaking using Task-Based Language Teaching (TBLT) can be seen from the teacher's point of view and students' point of view. From the teacher's side, the constraints are the role of teacher in giving instruction and the role of task itself. From the students' side, students' background knowledge, especially on language forms and vocabulary is the constraint found in the teaching speaking using TBLT. It appears when the students did the task in during task and in the reflection of performance session in post-task.

According to the findings, by using this method, the students can find it easier to express their idea since it emphasizes on the real communicative task. Then, by doing the real word tasks, the students sharpen their analytical thinking by themselves. The findings support the theories from previous researches using TBLT in teaching speaking, showing the same effects which improved students' speaking ability and made them more active in the class.

\section{SUGGESTIONS}

Based on the result of the study and conclusion, the researcher would like to suggest as follows:

1. English Teachers

English teachers are suggested to apply this method in teaching speaking.

2. Further Researchers

The findings of this study are expected to be used as a starting point for future researchers to conduct similar research in different field or task types. The future researchers are also expected to prepare the material well before applying TBLT as their research topic. 


\section{REFERENCES}

Burns, A., \& Joyce, H. 1997. Focus on speaking. Sydney: National Centre for English Language Teaching and Research.

Bygate, M., Skehan, P., \& Swain, M. 2001. Introduction. In, M. Bygate, P. Skehan, \& M. Swain (Eds.), Researching pedagogic tasks, second language learning, teaching and testing. Harlow: Longman.

Ellis, R. 2003. Task-based language learning and teaching. Oxford: Oxford University Press.

Fandana, R. 2013. Increasing students' speaking ability through problem solving at the first grade of SMAN 1 Simpang Pematang. University of Lampung. (Unpublished Script).

Hedge, T. 2000. Teaching and learning in the language classroom. Oxford: Oxford University Press.

Jones, L. 2007. The student-centered classroom. Cambridge: Cambridge University.

Lochana, M., \& Deb, G. 2006. Task based teaching: Learning English without tears. Asian EFL Journal, Vol (8) (3), pp 140-154.

Ormrod, J. E. 2006. Essentials of educational psychology. Colorado: Pearson Merrill Prentice Hall.

Richards, J. C. 1990. Conversationally speaking: Approaches to the teaching of conversation. New York: Cambridge University Press.

Sofyana, A. W. 2015. Task-based language teaching in improving students' speaking skill through cartoon story maker. Salatiga: State Institute for Islamic Studies (IAIN) Salatiga.

Swain, M. \& Lapkin, S. 2000. Task-based second language learning: The uses of the first language. Language Teaching Research 4/3: 251-74.

Willis, J. 1996. A framework for task-based learning. Harlow: Longman. 